\title{
Effect of Scientific Inquiry Learning Model on the Student's Generic Science Skill
}

\author{
Saima Putrini R. Harahap ${ }^{1}$ Ridwan A. Sani ${ }^{2}$ Mariati P. Simanjuntak ${ }^{2}$ \\ ${ }^{I}$ (Postgraduate Students at State University of Medan, Indonesia) \\ ${ }_{2}^{2}$ (Postgraduate Lecturer at State University of Medan, Indonesia) \\ Corresponding Author: Saima Putrini R. Harahap
}

\begin{abstract}
This research aims to analyze the effect of scientific inquiry learning model on the student's generic science skill (GSS). This research is a research quasi experimental with two group pretest-posttest design. The population of the research is all students of class X SMA Negeri 1 Batangkuis semester II academic year 2016/2017. The sample in this research taken as a cluster random sampling, that is as much as 2 class numbered 62 people. Class X MIA3 as a class experiment that taught scientific inquiry learning model consisting of 30 students, class X MIAI as control classes are taught with the conventional learning consists of 32 students. This research instrument using the generic science skill essay test that consists of 10 questions have been validated. The resulting data were analyzed using $t$-test results obtained. Based on the research, the average value of postes of control class is 66.69 and experimental class is 79.63. Test the hypothesis produce value the significance of $0.000<0.05$ which shows that the scientific inquiry learning model influences the students generic science skill.
\end{abstract}

Keywords: scientific inquiry learning model, generic science skill

Date of Submission: 07-07-2017

Date of acceptance: 17-07-2017

\section{Introduction}

Physics is a branch of natural science. Learning physics can be defined as the process of teaching and learning that studies natural occurrences. The process of building physics in students can begin with observing the symptoms and behavioral nature. The results of these observations can make students have an awareness of the scale observed. Symptoms and behaviors observed nature made in the symbolic language that it can be explained by many laws. These laws are linked so that the theory of the demonstrate found skeletons of logic conformed to basic. Students perform a number of logical inference to question the logical consequence that can be taken from such laws, so the students can deduce causal nature of the symptoms diamatinya. Students explain the causal nature of the symptoms observed in the form of mathematical modeling and propose an alternative resolution in order to be resolved appropriately, so that the resulting new concepts in students. A series of activities to build the concept is an indicator of generic science skill (GSS).

GSS is a skill that can be used to study the various concepts and solve problems in science [1]. GSS is very useful for students to solve problems in physics on the surrounding environment as well as the time the learning process takes place. GSS is a skill that is used in general in a variety of scientific work [2].

The importance of GSS does not match what is expected. Based on the results of observation on SMAN 1 Batangkuis can be said students still undeveloped GSS because students are not trained to have the GSS. Students rarely do the teaching, so that students are not accustomed to do observations, building concept, applying the language of symbolic and mathematical modeling. Should the student have the skills that deal in strengthening cognitive structure in understanding, mastering and applying the concept of physics so that students can complete the physical problems from simple up to complex, where skills are the hallmark of GSS.

Less growing GSS students in learning, one of which is influenced by learning model is less varied. Tackling problems in the above learning, need to have a resolution. One of the efforts to improve students is by applying GSS model learning of scientific inquiry. Scientific inquiry learning model is a model of learning which involves the most throughout the students ' ability to find and investigate the systematic, critical, logical, analytical so that students can formulate its own discovery with aplomb [3]. According to Hussain [4] learning model of scientific inquiry is better than conventional learning model. This is because a model learning scientific inquiry can help to provide an explanation which is terkonstruksi so that students learn more yourself through the investigation, resulting in the investigation of the students will be accustomed to observing, formulating problems in mathematical modeling, connecting linkages two rules and make students to build up a new concept in his knowledge, to which some of these components is an indicator of GSS. 
Scientific inquiry learning model refers to the various ways in which scientists study the nature and proposes an explanation based on evidence gained from their experiences. Scientific inquiry also refers to the students where they develop knowledge and understanding of scientific ideas, as well as an understanding of how scientists study natural [5]. Students are guided by teachers in understanding the concept through potentially experiencing unplanned experiment. According to Joyce [6] a model of learning scientific inquiry is designed to engage students in inquiry issue really original way confronts students at investigation, help students identify methodological problems of conceptual or in the field and invite the students to be able to devise a way to resolve the issue.

Scientific inquiry learning model aims to help learners develop intellectual discipline and skills required as well as invites learners to be active in solving a problem, so that this very precise model used to improve student skills a GSS which is used to study the various concepts in solving various problems in science. The use of scientific inquiry learning model this can encourage learners to think and work on their own initiative, are objective, honest and open. Through this learning model, students are exposed to a scientific activities to train skilled students in obtaining and processing information through the activity of thinking by following the scientific method, such as the skillful conduct of observation, measurement, classification, the withdrawal of the conclusions, and pengkomunikasian results. Students are directed to develop its own talent in the process and find out for yourself the scientific knowledge.

\section{Method}

This research is a research quasi experimental with pretest-posttest group two design. The population of the research was the whole grade X SMA Negeri 1 Batangkuis school year 2016/2017. Samples taken in the research cluster random sampling, that is as much as 2 class numbered 62 people. Class X MIA3 as a class experiment that taught scientific inquiry learning model consisting of 30 students, class X MIA2 as control classes are taught with the conventional learning consists of 32 students. Research instrument using the test essay GSS consisting of 10 questions have been validated. GSS data generated were analyzed using t-test with the help of SPSS 20 .

Result

\section{Result and Discussion}

Pretest data is a GSS essay test consisting of 10 questions. Pretes were given to see students' early abilities in both classes. A description of GSS pretest data for the experimental and control classes can be seen in Table 1.

Table 1. Pretes of Generic Science Skill

\begin{tabular}{|l|c|c|c|}
\hline \multicolumn{4}{|c|}{ Pretes of Generic Science Skill } \\
\hline Class & $\mathrm{N}$ & Mean & Std. Deviation \\
\hline Eksperiment & 30 & 41,20 & 9,69 \\
\hline Control & 32 & 37,16 & 8,28 \\
\hline
\end{tabular}

Based on the data in Table 1 it can be seen that the average of pretest values in the experimental class and control classes are 41.20 and 37.16, respectively. Pretest implementation is done to see the students' initial ability by using different test, provided that the data com e from normal and homogenous distributed populations. The results of pretest different test data are presented in Table 2.

Table 2. Test of Differences in Experimental Class and Control Class

\begin{tabular}{|c|c|c|c|c|c|c|c|c|}
\hline & & \multicolumn{7}{|c|}{ t-test for Equality of Means } \\
\hline & & \multirow[t]{2}{*}{$\mathrm{t}$} & \multirow[t]{2}{*}{$\mathrm{df}$} & \multirow{2}{*}{$\begin{array}{l}\text { Sig. (2- } \\
\text { tailed) }\end{array}$} & \multirow{2}{*}{$\begin{array}{l}\text { Mean } \\
\text { Diff. }\end{array}$} & \multirow{2}{*}{$\begin{array}{l}\text { Std. Error } \\
\text { Difference }\end{array}$} & \multicolumn{2}{|c|}{\begin{tabular}{|c|}
$95 \%$ Confidence Interval of the \\
Difference
\end{tabular}} \\
\hline & & & & & & & Lower & Upper \\
\hline \multirow[b]{2}{*}{ Value } & Equal variances assumed & $-1,769$ & 60 & 0,082 & $-4,044$ & 2,286 & $-8,616$ & 0,528 \\
\hline & $\begin{array}{l}\text { Equal variances not } \\
\text { assumed }\end{array}$ & $-1,760$ & 57,220 & 0,084 & $-4,044$ & 2,297 & $-8,644$ & 0,556 \\
\hline
\end{tabular}

Table 2 shows the significance value of 0.082 and 0.084 , because the significant value is greater than 0.05 then the accepted H0 or the GSS score of the students in the pretest tests of the two classes does not differ significantly which means the two classes have the same GSS. Different treatments were given for 3 meetings in the experimental class and control class. The experimental class uses scientific inquiry and control class learning models using conventional learning. The application of scientific inquiry learning model begins by forming a group. The teacher gives problems related to the subject matter through the student worksheet (TSW), then instructed to make hypotheses and carry out the practicum. Students make the results and discussion of the lab. Researchers analyze the results of workmanship TSW that have been done by students at each meeting. The results of the TSW assessment can be viewed in Figure 1.

DOI: 10.9790/7388-0704016064 www.iosrjournals.org $\quad 61 \mid$ Page




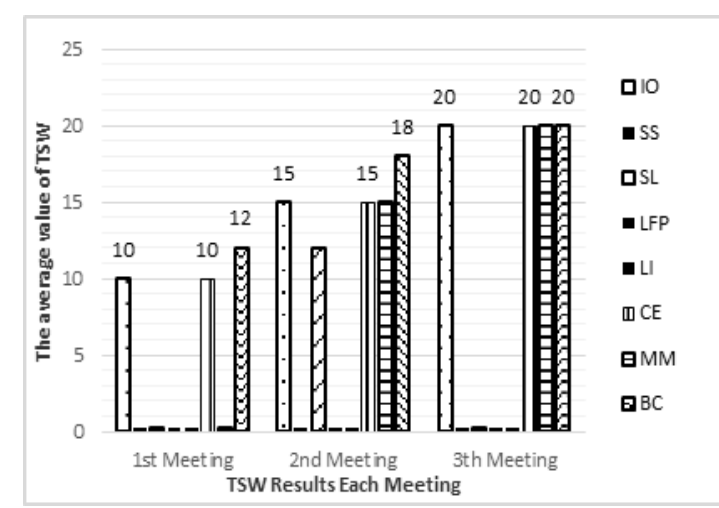

Figure 1. Average TSW Results by GSS Indicators

Based on Figure 1 of TSW results can be seen the average value of students based on the GSS indicator. Student scores for indirect observation indicators (IO), cause and effect (CE), mathematical modeling (MM) and build concept (BC) have an increase in each meeting. This is because the TSW students are required to make observations, connect the linkage of two or more variables, reveal the problem in the form of formulas and add new concepts. Logical framework of principle (LFP), logical inference (LI), and sense of scale (SS) indicators have no value because they are not required on TSW.

Unlike the case in the control class, learning is carried out with conventional learning. The teacher provides both oral and written explanations based on a handbook owned by the students. Students are given training questions to master the subject matter that has been given. Students are required to answer questions and write them in their practice book. This is the core of the treatment given by the teacher in the control class.

After both classes get treatment, then both classes are done postes GSS testing. Description of GSS postes data is presented in Table 3 .

Table 3. Postes of Generic Science Skill

\begin{tabular}{|c|c|c|c|}
\hline \multicolumn{4}{|c|}{ Postes of Generic Science Skill } \\
\hline Class & N & Mean & Std. Deviation \\
\hline Exsperiment & 30 & 79,63 & 6,67 \\
\hline Control & 32 & 66,69 & 8,81 \\
\hline
\end{tabular}

Based on Table 3, the average GSS of the students in the experimental class after treatment is 79.63 and for the control class is 66.69 , where the average GSS score of the students in the experimental class is greater than the control class.

GSS tests that have been answered by the students are analyzed per point because of the problem. This analysis is useful to look at which indicators are difficult for students. The data analyzed were students' GSS pretest and postes data on the control class and experimental class shown in Table 4 .

Table 4. The Percentage Value Of Each Student's Grain Problem

\begin{tabular}{|c|c|c|c|c|c|c|}
\hline \multirow{2}{*}{ No. } & \multirow{2}{*}{$\begin{array}{c}\text { GSS } \\
\text { Indicator }\end{array}$} & \multirow{2}{*}{ Max. Score } & \multicolumn{2}{|c|}{ Pretes } & \multicolumn{2}{c|}{ Postes } \\
\cline { 4 - 7 } & & Control (\%) & Exp. (\%) & Control (\%) & Exp. (\%) \\
\hline 1. & IO & 8 & 55 & 44 & 68 & 89 \\
\hline 2. & LI & 8 & 33 & 45 & 73 & 73 \\
\hline 3. & SL & 10 & 69 & 45 & 84 & 78 \\
\hline 4. & MM & 10 & 48 & 41 & 65 & 72 \\
\hline 5. & LFP & 10 & 50 & 29 & 62 & 73 \\
\hline 6. & SS & 12 & 24 & 40 & 58 & 95 \\
\hline 7. & BC & 8 & 31 & 60 & 83 & 80 \\
\hline 8. & CE & 12 & 26 & 36 & 63 & 73 \\
\hline 9. & SS & 12 & 25 & 39 & 60 & 84 \\
\hline 10. & BC & 10 & 26 & 41 & 63 & \\
\hline
\end{tabular}

Evidence :

$\begin{array}{llll}\text { IO } & \text { : indirect observation } & \text { LFP } & : \text { logical framework of principle } \\ \text { CE } & \text { : cause and effect } & \text { LI } & : \text { logic inference } \\ \text { SS } & \text { : sense of scale } & \text { MM } & : \text { mathematical modeling } \\ \text { SL } & : \text { symbolic language } & \text { BC } & : \text { build concept }\end{array}$


Based on Table 4. we can see the differences in each generic science skills indicator of the students in the control and experimental class. The highest percentage of students' answers to the experimental class was $60 \%$ for the pretest and $95 \%$ for postes with the conceptual construct (MK) indicator on item number 7 . This is because when the teacher's learning exposes the student to the problem, students then hypothesize and do the lab to find How to solve the problem so as to make students find a new concept in their knowledge. The percentage of students' lowest answers to the experimental class is $29 \%$ for pretest and $72 \%$ for postes with logical principle logic indicator (KL) on question number 5. This is because when students do TSW, students are not required to have a logical principle. The highest percentage of students' answers to the control class was $69 \%$ for pretest and $84 \%$ for postes with symbolic language indicator on item number 3 . This is because the students learn to memorize formulas and physical symbols. The lowest percentage of students' answers to the control class was $24 \%$ for pretest and $58 \%$ for postes with a sense of scale indicator on item number 6 . This is because in the learning process students are never exposed to problems related to the scale of a magnitude.

The data were analyzed using $t$ test postes subject data derived from a population of Gaussian and homogeneous. The results of the test data processing t postes presented in Table 5.

Table 5. T-test in Experimental Class and Control Class

\begin{tabular}{|c|c|c|c|c|c|c|c|c|}
\hline & \multicolumn{7}{|c|}{ t-test for Equality of Means } \\
\hline & & \multirow[t]{2}{*}{$\mathrm{t}$} & \multirow[t]{2}{*}{ df } & \multirow{2}{*}{$\begin{array}{l}\text { Sig. (2- } \\
\text { tailed) }\end{array}$} & \multirow{2}{*}{$\begin{array}{c}\text { Mean } \\
\text { Difference }\end{array}$} & \multirow{2}{*}{$\begin{array}{l}\text { Std. Error } \\
\text { Difference }\end{array}$} & \multicolumn{2}{|c|}{$\begin{array}{l}95 \% \text { Confidence Interval of the } \\
\text { Difference }\end{array}$} \\
\hline & & & & & & & Lower & Upper \\
\hline \multirow{2}{*}{ Value } & Equal variances assumed & $-6,006$ & 60 & 0,000 & $-11,979$ & 1,994 & $-15,969$ & $-7,990$ \\
\hline & Equal variances not assumed & $-6,060$ & 57,497 & 0,000 & $-11,979$ & 1,977 & $-15,937$ & $-8,022$ \\
\hline
\end{tabular}

Based on Table 5, the value of significance is obtained. of 0,000 . The significance value of 0.000 $<0.05$, then it can be said that the test results reject $\mathrm{H}_{0}$ or accept $\mathrm{H}_{\mathrm{a}}$ in the level of alpha $5 \%$, thus it can be concluded that the model of scientific inquiry study influences the generic skills of science.

\section{Discussion}

The results obtained in this study indicate that the scientific inquiry learning model influences the generic skills of students' science. This can be seen from the average value of pretest students in the experimental class is 41.20 and after being given treatment using scientific inquiry learning model, student postes score of 79.63. This is because the stages of the scientific inquiry learning model can improve students' generic science skills.

Stages of the scientific inquiry instruction model is the presentation of the problem to the students covering the methodology used in the investigation, then the students formulate the problems presented by the teacher so that students can identify the difficulties in the investigation. Students identify problems and find ways to overcome adversity. The scientific inquiry learning model is a learning model that develops a scientific way of thinking that helps to provide constructed explanations so that students learn more by themselves to investigate, solve and find solutions to problems [7].

The results of this study are in line with Hussain's research [4] which states that the scientific inquiry learning model is better than conventional learning model. This is because the scientific inquiry learning model can make students more curious about the problems conveyed by the teacher. This research is also in line with research conducted by Sihotang [8] which states that the use of scientific inquiry teaching model can encourage students to think and work on their own initiative, objective, honest and open, supported by Sahyar [9] Using conceptual change to improve students 'cognitive abilities and students' science process skills, which used a scientific inquiry teaching model that stated better than conventional learning.

Through this learning model, students are faced with a scientific activity to train skilled students in obtaining and processing information through thinking activities by following scientific methods, such as skilled in observing, measuring, classifying, drawing conclusions, and communicating the findings, so it can be concluded that the model Scientific inquiry learning can improve student learning outcomes [10]. The scientific inquiry learning model is a learning model that involves maximally all students' ability to search and investigate in a systematic, critical, logical, analytical way so that students can formulate their own discovery with confidence (Dumbrajs, 2011).

Based on the above explanation, it is clear that the scientific inquiry teaching model is better than conventional learning, because in the conventional learning, the teacher conveys the information directly to the students by arranging the lesson time to achieve some clearly defined goals as efficiently as possible so that the learning is teacher centered will Reducing students' opportunities to hone generic science skills of students. 


\section{Conclusion}

Based on the results of research and discussion it can be obtained conclusion, namely the model of scientific inquiry learning affects the generic skills of science students. Based on the average score of students taught using scientific inquiry learning model obtained for 79.63 and for conventional learning of 66.69. Hypothetical test performed resulted a significance value of $0.000<0.05$ which indicates that the scientific inquiry learning model influences the generic skills of science students.

Based on the conclusions that have been presented, in accordance with the results obtained research, then the researcher suggests:

1. Researchers are further suggested to construct the student worksheets (TSW) that train students to have generic science skills.

2. For further research is suggested before starting the learning process first explained to the student how the implementation of scientific inquiry learning model, so that at the time of implementation of learning the students already understand what will be done and not take up time for the other learning phases.

3. Researchers are then advised to consider the allocation of time in the process of scientific inquiry learning so as to achieve the goal of learning maximally.

4. Researchers are further advised to better train students in asking questions relating to problems posed to students. It aims to enable students to find clues to answer the cause of the problem.

\section{References}

[1] Brotosiswoyo, B.S. 2000. Hakikat Pembelajaran MIPA di Perguruan Tinggi. Jakarta : Proyek Pengembangan Universitas terbuka. Departemen Pendidikan Nasional.

[2] Mohamed dan Jaafar, M. 2009. Using Cooperative Learning to Improve Generic Skills among University Students. International Conference on Teaching and Learning in Higher Education. 1(2): 141-148

[3] Ali, M. \& Spencer, M. 2012. Scientific Inquiry based Professional Development Models in Teacher Education. Educational Sciences: Theory \& Practice, Vol. 12, No. 1, 514-521.

[4] Hussain, A., Azeem, M., dan Shakoor, A. 2011. Physics Teaching Methods : Scientific Inquiry Vs Traditional Lecture. International Journal of Humanities and Social Science, 1(2): 163-169.

[5] National Institutes Of Health. 2005. Doing Science: The Process Of Scientific Inquiry. Colorado Springs: BSCS

[6] Joyce, B., Weil, M., dan Calhoun, E. 2009. Models of Teaching. Yogyakarta : Pustaka Pelajar.

[7] Bao. 2013. Affective Factors in STEM Learning and Scientific Inquiry: Assessment of Cognitive Conflict and Anxiety, Special Issue of Research on Education Assessment and Learning. Ohio: Department of Physics Ohio State University.

[8] Sihotang, D. C. N. 2014. Analisis model pembelajaran scientific inquiry dan sikap ilmiah pada materi listrik dinamis. Jurnal Pendidikan Fisika, 1(2): 15-26.

[9] Sahyar. 2017. The Effect of Scientific Inquiry Learning Model Based on Conceptual Change on Physics Cognitive Competence and Science Process Skill (SPS) of Student at Senior Hihg school. Journal of Education and Practice. Vol.8, No.5.

[10] Lederman, N.G., Lederman, J.S., dan Antink, A. 2013. Nature of science and scientific inquiry as contexts for the learning of science and achievement of scientific literacy. International Journal of Education in Mathematics, Science and Technology, 1(3), $138-147$.

[11] Dumbrajs, S. 2011. Towards Meaningful Learning Through Inquiry. Eurasian Journal of Physics and Chemistry Education, Vol. 3, No. 1, 39-50. 64. 